\title{
Potensi Kekayaan Alam Kelautan Mendukung Kebijakan Kemdiknas dalam Pengembangan SMK pada Era Otonomi Daerah
}

\author{
Subijanto \\ Bagian Perencanaan dan Penganggaran Sekretariat Balitbang \\ e-mail: subijanto2010@gmail.com
}

\begin{abstract}
Abstrak: Tujuan penyelenggaraan pendidikan sekolah menengah kejuruan (SMK) yaitu untuk menyiapkan peserta didik sebagai pekerja tingkat menengah. Di samping itu, penyelenggaraan SMK juga bertujuan memberi kesempatan kepada peserta didik yang memenuhi kemampuan dan persyaratan untuk melanjutkan pendidikan yang lebih tinggi (vokasi, profesi, dan akademik). Sebaliknya, penyelenggaraan pendidikan sekolah menengah atas (SMA) bertujuan untuk memberikan kompetensi akademik kepada peserta didik ketika melanjutkan pendidikan ke jenjang yang lebih tinggi. Perkembangan data akhirakhir ini menunjukkan bahwa tamatan SMA yang melanjutkan pendidikan ke jenjang yang lebih tinggi hanya mencapai kurang lebih 33 persen. Akibatnya, tamatan SMA memerlukan keterampilan dasar untuk dapat bekerja di bidang tertentu. Kondisi yang demikian diantisipasi oleh pemerintah daerah untuk mengembangkan penyelenggaraan pendidikan SMK sebagai alternatif jawaban dalam upaya meningkatkan pemenuhan kebutuhan tenaga kerja tingkat menengah sesuai dengan potensi daerah masing-masing.
\end{abstract}

Kata kunci: kebijakan Kemdiknas, sekolah menengah kejuruan, otonomi daerah, perikanan, dan kelautan.

\begin{abstract}
The aim of providing vocational school is to prepare student in order to ready to certain work. On the other hand, the aim of its is to give student who has a competent and requirement for continues studying to higher level (vocational, proffesional, and academic path). Otherwise, the aim of providing senior secondary school is to prepare student to continues studying to higher level (academic path). The development of latter data shown that senior secondary graduates school who are able to continues studying for higher leven more or less 33 percent. The impacts of this condition is graduates senior secondaray school need to have certain basic skill for getting a job. To anticipate this his condition, the district government could be developed more vocational schol as an alternatif for answering problem to fulfill the job seekers in midel level of labour force according to the potential in each region.
\end{abstract}

Key words: MoNE policy, vocational school, regional otonomy, fishery, and maritim

\section{Pendahuluan}

Berdasarkan Undang-Undang Sistem Pendidikan Nasional, pendidikan menengah terdiri atas pendidikan menengah umum dan pendidikan menengah kejuruan (UU No: 20/2003, Pasal 18, ayat 2). Selanjutnya, sekolah menengah atas (SMA) merupakan bentuk satuan pendidikan umum dan sekolah menengah kejuruan (SMK) sebagai bentuk satuan pendidikan menengah kejuruan. Penyelenggaraan SMA dimaksudkan untuk memberikan kompetensi akademik kepada peserta didik untuk melanjutkan pendidikan yang lebih tinggi, sebaliknya, SMK lebih menekankan pada penyiapan peserta didik untuk bekerja pada bidang tertentu. Namun, penyelenggaraan SMK juga memberikan kesempatan kepada peserta didik yang memiliki persyaratan dan kemampuan untuk melanjutkan pendidikan vokasi, profesi maupun akademik (tujuan ganda).

Data Balitbang (2009) menunjukkan bahwa jumlah SMA negeri dan swasta di Indonesia berjumlah 8.036 dengan jumlah peserta didik 3.758.893 orang siswa, sedangkan jumlah SMK negeri dan swasta berjumlah 5.300 dengan jumlah peserta didik 2.738 .962 orang siswa. Jumlah tersebut menimbulkan kesan bahwa Pemerintah cenderung menciptakan generasi penerus bangsa untuk melanjutkan ke pendidikan akademik. dibandingkan dengan penyiapan tenaga kerja tingkat menengah melalui pendidikan kejuruan.

Isu yang masih sering muncul di kalangan masyarakat bahwa melanjutkan pendidikan ke SMK merupakan "pilihan kedua" manakala tamatan SMP tidak diterima di SMA. favorit. Hal ini 
mengakibatkan citra SMK menjadi kurang menarik dan hanya diminati oleh lulusan SMP yang status ekonomi orang tuanya tergolong kurang mampu (kalangan menengah ke bawah). Begitu pula, kesan masyarakat industri selama ini yang masih melekat bahwa sikap, disiplin, kemampuan intelektual, pengendalian emosi, dan keterampilan tamatan SMK masih serba tanggung. Akibatnya, beberapa perusahaan/industri cenderung menerima karyawan dengan tidak membedakan apakah ia berasal dari tamatan SMK maupun SMA. Bahkan, ada yang lebih ekstrim dengan lebih baik menerima tamatan SMA daripada tamatan SMK.

Asumsi tersebut menggambarkan bahwa lulusan SMA pada umumnya memiliki daya nalar yang lebih tinggi jika dibandingkan dengan lulusan SMK. Meskipun tamatan SMA pada awal bekerja kurang memiliki keterampilan sebagaimana dimiliki oleh para lulusan SMK, namun setelah mendapat pelatihan (in service training) mereka lebih cepat meningkatkan keterampilan dan penalarannya jika dibandingkan dengan pekerja yang berasal dari tamatan SMK. Isu tersebut secara berangsur-angsur tereliminir manakala para lulusan SMK secara nyata mampu menunjukkan kesiapan untuk bekerja dengan bekal kompetensi sesuai dengan tuntutan kerja (link and match). Di samping itu, faktor political will dari Pemerintah pusat maupun daerah untuk mengembangkan dan mewujudkan sekolah kejuruan (SMK) yang unggul sesuai kebutuhan pasar kerja (basic demand) sangat memungkinkan untuk mengubah pandangan sekolompok masyarakat yang masih menomorduakan SMK.

Berbagai potensi kekayaan alam di wilayah Negara Kesatuan Republik Indonesia (NKRI) masih belum diolah dan diberdayakan secara optimal. Potensi kekayaan alam tersebut dapat diimbangi dengan penyiapan sumber daya manusia (SDM) yang berkualitas sebagai calon tenaga kerja dengan cara mengembangkan sekolah kejuruan (SMK) unggulan di daerah sesuai dengan potensi dan kebutuhan pembangunan daerah setempat. Salah satu potensi kekayaan alam yang perlu dikembangkan adalah potensi kelautan. Potensi kelautan di wilayah Indonesia sampai saat ini masih belum diberdayakan sebagaimana mestinya. Pemberdayaan potensi kekayaan laut (ikan dan rumput laut) misalnya, jika dikelola dengan optimal dapat menciptakan lapangan kerja. Lapangan kerja erat kaitannya dengan pendidikan dan pelatihan kejuruan. Salah satu upaya untuk meningkatkan kualitas SDM yaitu melalui pendidikan kejuruan.

Masyarakat pesisir dan pulau-pulau kecil yang sebagian besar terdiri atas nelayan, pembudidaya ikan, pengolah dan pedagang hasil laut, serta masyarakat lainnya yang kehidupan sosial ekonominya sangat tergantung dari sumber daya alam kelautan, merupakan kelompok masyarakat yang pada umumnya masih rendah pendapatannya (miskin). Hal itu sekaligus mencerminkan tingkat pendidikan masyarakat setempat pada umumnya dan rendahnya kualitas SDM pada khususnya sekaligus mempengaruhi pola pikir dalam kehidupannya di masyarakat. Pola pikir tersebut mempengaruhi masih kukuhnya pendirian yang mengakibatkan pembiasaan (budaya) sulit untuk maju. Budaya menolak untuk melakukan pembangunan di daerahnya merupakan kendala yang sangat medasar yang harus dicarikan berbagai alternatif pendekatan dan solusinya dalam proses pembangunan dan pemberdayaan masyarakat. Di samping itu, ketertinggalan masyarakat pesisir juga disebabkan oleh karena terbatasnya dalam mengakses sumber permodalan, lemahnya infrastruktur atau terbatasnya sarana dan prasarana, lemahnya kelembagaan sosial ekonomi masyarakat di tingkat desa, dan terbatasnya akses untuk memperoleh informasi dan komunikasi sesuai dengan perkembangan ilmu pengetahuan dan teknologi.

Mengacu pada latar belakang permasalahan yang dirumuskan, salah satu bidang kejuruan apakah yang berpotensi untuk dikembangkan di SMK dalam rangka menyiapkan calon tenaga kerja tingkat menengah sejalan dengan kebijakan otonomi daerah dan tuntutan global? Tujuan penulisan artikel ini adalah memberikan sumbang saran pemikiran kepada masyarakat terutama pemerintah daerah untuk mengembangkan SMK dalam upaya menghasilkan calon tenaga tingkat menengah untuk memenuhi kebutuhan tenaga kerja di daerah dalam menunjang pembangunan daerahnya pada era otonomi. 
Kajian Literatur dan Pembahasan

\section{Pengertian otonomi daerah dan implikasi terhadap SMK}

Secara sederhana, otonomi daerah dalam hal ini dapat diartikan sebagai pemberian wewenang Pemerintah Pusat kepada pemerintah daerah untuk mengatur daerahnya sendiri (otonom). Salah satu dampak dari otonomi daerah di bidang pendidikan adalah pemberian sebagian wewenang Pemerintah (Kemdiknas Pusat) ke kantor dinas pendidikan (kabupaten/kota) dan/ atau pemberian kewenangan langsung ke sekolah untuk mengatur program dan kegiatan sekolah dalam bentuk manajemen berbasis sekolah (school based management). Pelaksanaan pengembangan manajemen berbasis sekolah merupakan pemberian kewenangan kepala sekolah untuk merencanakan, mengatur, melaksanakan, mengembangkan dan mengeva-luasi program pendidikan melalui kerja sama dengan masyarakat (orang tua, tokoh masya-rakat, masyarakat dunia usaha/industri, dsb). Dengan demikian, tugas dan wewenang Kemdiknas Pusat dalam bidang tertentu dilakukan secara desentralisasi.

Dalam mengantisipasi perubahan terhadap pendidikan menengah kejuruan, Satuan Tugas Pengembangan Pendidikan dan Pelatihan Kejuruan dalam Buku Putih "Keterampilan 2020", merumuskan beberapa dimensi reformasi pendidikan yang dapat dijadikan acuan dalam pengembangan sistem pendidikan kejuruan dan pelatihan menghadapi era globalisasi. Salah satu contoh dimensi masa lalu adalah dari sistem pengelolaan yang terpusat menuju masa depan dengan sistem pengelolaan yang terdesentralisasi. Perubahan sistem pendidikan kejuruan dan pelatihan masa lalu menuju masa depan disajikan pada Tabel 1.

\section{Potensi Sumberdaya Alam Kelautan}

Negara Kesatuan Republik Indonesia yang berbentuk kepulauan, merupakan negara bahari yang $2 / 3$ luas wilayahnya berupa perairan dan $1 /$ 3 wilayahnya berupa daratan. Memiliki panjang garis pantai sekitar $81.000 \mathrm{~km}$ (terpanjang kedua

Tabel 1. Perubahan dimensi-dimensi reformasi pendidikan dan pelatihan kejuruan

\begin{tabular}{|l|c|l|}
\hline \multicolumn{1}{|c|}{ Masa lalu } & Menuju & \multicolumn{1}{c|}{ Masa depan } \\
\hline $\begin{array}{l}\text { Sistem "supply driven" atas kebutuhan } \\
\text { sosial masyarakat luas }\end{array}$ & - & $\begin{array}{l}\text { Sistem "demand-driven" yang } \\
\text { dipandu kebutuhan pasar kerja }\end{array}$ \\
\hline $\begin{array}{l}\text { Sistem berbasis sekolah dengan } \\
\text { pemberian ijazah bagi yang lulus ujian } \\
\text { akhir }\end{array}$ & & $\begin{array}{l}\text { Sistem pendidikan dan pelatihan yang } \\
\text { memberi kompetensi, sesuai dengan } \\
\text { standar nasional yang baku }\end{array}$ \\
\hline $\begin{array}{l}\text { Sistem berbasis sekolah melalui alur } \\
\text { dan proses yang kaku }\end{array}$ & & $\begin{array}{l}\text { Sistem pendidikan dan pelatihan yang } \\
\text { lentur dengan prinsip multi entry dan } \\
\text { multi exit }\end{array}$ \\
\hline $\begin{array}{l}\text { Tidak mengakui kemampuan yang telah } \\
\text { dimiliki sebelumnya }\end{array}$ & - & $\begin{array}{l}\text { Sistem yang secara tegas mengakui } \\
\text { kompetensi di mana pun dan } \\
\text { bagaimana pun caranya diperoleh }\end{array}$ \\
\hline $\begin{array}{l}\text { Sistem berbasis sekolah dengan } \\
\text { orientasi program studi kejuruan yang } \\
\text { baku }\end{array}$ & & $\begin{array}{l}\text { Sistem pendidikan dan pelatihan yang } \\
\text { mengacu pada profesi dan } \\
\text { keterampilan }\end{array}$ \\
\hline $\begin{array}{l}\text { Pendidikan dan pelatihan berfokus pada } \\
\text { sektor formal }\end{array}$ & - & $\begin{array}{l}\text { Pendidikan dan pelatihan untuk sektor } \\
\text { formal dan informal }\end{array}$ \\
\hline $\begin{array}{l}\text { Pemisahan antara pendidikan dan } \\
\text { pelatihan }\end{array}$ & - & $\begin{array}{l}\text { Mengintegrasikan secara terpadu } \\
\text { antara pendidikan dan pelatihan yang } \\
\text { bersifat kognitif dan berdasarkan ilmu } \\
\text { pengetahuan }\end{array}$ \\
\hline Sistem pengelolaan yang terpusat & & $\begin{array}{l}\text { Sistem pengelolaan yang } \\
\text { terdesentralisasi }\end{array}$ \\
\hline $\begin{array}{l}\text { Lembaga/organisasi yang sepenuhnya } \\
\text { dibiayai dan dioperasikan oleh } \\
\text { pemerintah }\end{array}$ & - & $\begin{array}{l}\text { Lembaga/organisasi yang mampu } \\
\text { melakukan swakelola dan swadana } \\
\text { dengan subsidi pemerintah pusat }\end{array}$ \\
\hline
\end{tabular}

Sumber : Keterampilan 2020, Depdikbud, 1995. 
di dunia setelah Canada) dan memiliki kurang lebih 17.000 pulau-pulau kecil dengan berbagai sumber daya alamnya. Menyadari sepenuhnya bahwa kekayaan sumber daya alam di daratan semakin lama semakin habis maka perlu mengalihkan perhatian pada upaya pengelolaan sumber daya alam di laut yang belum diberdayakan. Pemberdayaan potensi kekayaan laut dimaksudkan untuk mencukupi kepentingan hajad hidup orang banyak bangsa Indonesia. Untuk itu, diperlukan SDM yang berkualitas yang memiliki pengetahuan, pemahaman, dan keahlian dalam mengelola sumber daya alam yang ada di laut (Pratikto, 2005).

Salah satu cara untuk mewujudkan SDM tersebut adalah melalui pengembangan SMK perikanan laut khususnya daerah yang memiliki wilayah pesisir. Melalui SMK perikanan diharapkan dapat menghasilkan tamatan yang handal, terampil dan produktif melalui pembelajaran yang kontekstual dan aplikatif di sekolah. Hal ini sekaligus sebagai awal untuk mengalihkan pola kultur agraris di darat menuju pola kultur agraris kelautan (bahari). Dalam jangka pendek, hal tersebut dapat dilakukan melalui pemberian pemahaman akan pentingnya pelestarian kekayaan di laut dan pengelolaan sumber daya alamnya. Dalam membekali keterampilan spesifik tentang pengelolaan dan pengolahan sumber daya alam di laut sebagai perubahan pola pikir (academic skill) dan kejuruan (vocational skill) dapat dikembangkan SMK Perikanan (laut).

Dalam upaya merintis pendidikan kebaharian, baik melalui pendidikan jalur formal maupun nonformal kerja sama dengan instansi lain yang terkait sangat diperlukan. Penandatanganan nota kesepahaman (MoU) antara Departemen Pendidikan Nasional dengan Departemen Kelautan Nomor 06/XII/KB/2004 dan Nomor 09/ KB/Dep. KP/2004, tanggal 14 Desember 2004 dapat dijadikan salah satu dasar pertimbangan untuk mengembangkan sekolah berwawasan kebaharian di Indonesia (SMK perikanan) sekaligus sebagai pendukung kebijakan Kemdiknas dalam mengubah proporsi jumlah SMK: SMA dapat terwujud. Daerah pesisir merupakan wilayah yang sangat potensial untuk dikembangkan menjadi pusat-pusat kegiatan masyarakat seperti pusat perdagangan dan jasa, pusat industri perikanan, pusat pelabuhan dan transportasi, pusat pendidikan dan kebudayaan, pusat penelitian, dan pusat pemerintahan sesuai dengan potensinya masing-masing.

Menurut Pratikto (2005), saat ini terdapat sekitar 140 juta jiwa atau $60 \%$ penduduk Indonesia tinggal di wilayah pesisir selebar $50 \mathrm{~km}$ dari pantai. Indonesia yang dikenal dengan "nusantara" terdiri atas pulau-pulau yang berada di antara dua samudera. Namun, dalam kurun waktu 60 tahun kultur yang dibangun dalam pendidikan bahwa negara kita merupakan negara agraris dan bangsa kita adalah bangsa agraris. Sebenarnya pengenalan yang dilakukan oleh para pendahulu kita pada bidang kebaharian telah tercermin dalam pengenalan secara dini melalui lagu anak-anak di sekolah dasar mengenai "nenek moyangku orang pelaut, dst". Ini menandakan bahwa sebenarnya para pendahulu bangsa ini telah menggeluti pemberdayaan kebaharian sebelum Indonesia merdeka. Bahkan secara kelembagaan, saat ini telah terbentuk Dewan Kelautan Indonesia (DEKIN) yang para anggotanya terdiri atas wakil-wakil lintas kementerian (termasuk Kemdiknas) dan organisasi profesi di bidang kelautan dan perikanan. Di masa depan, dalam pengembangan kelautan/kemaritiman diharapkan Indonesia merupakan negara maritim yang maju, jaya, dan mandiri.

Untuk mengubah orientasi kultur ini tidaklah semudah membalikkan telapak tangan, namun memerlukan tahapan-tahapan yang terencana dengan sistemik dan komprehensif, berkesinambungan, serta adanya kemauan politik (political will) dari Pemerintah Pusat dan pemerintah daerah dalam mewujudkan hal dimaksud. Di samping itu, diperlukan SDM yang memiliki kemampuan untuk memberdayakan secara efektif kekayaan alam, terutama kelautan dan perikanan untuk kemakmuran rakyat. Dengan demikian, pengembangan pendidikan melalui SMK merupakan bagian integral upaya Pemerintah Pusat dan pemerintah daerah secara komprehensif untuk mengubah orientasi kultur agraris menjadi kultur bahari secara sistemik, bertahap dan berkesinambungan, serta dijadikan sebagai salah satu sumber daya yang dapat menopang perekonomian rakyat Indonesia.

Sindu, dkk (2005) menyatakan bahwa potensi kekayaan laut di Indonesia sebagaimana 
Tabel 2. Potensi Kekayaan Laut Indonesia

\begin{tabular}{|c|l|l|}
\hline No & \multicolumn{1}{|c|}{ Potensi } & \multicolumn{1}{c|}{ Keterangan } \\
\hline 1 & Luas laut & $5.800 .000 \mathrm{~km}^{2}$ \\
\hline 2 & Laut Nusantara & $3.100 .000 \mathrm{~km}^{2}$. \\
\hline 3 & Laut ZEEI & $2.700 .000 \mathrm{~km}^{2}$ \\
\hline 4 & Sumberdaya laut & \\
& a. Flora & 28.000 species \\
& b. Fauna & 350.000 species \\
& c. Mikroba & 110.000 species \\
& d. Terumbu Karang & 600.000 species \\
\hline
\end{tabular}

Sumber: Sindu A., S. Handoto dan Adi Saputra (2005)

ZEEI = Zona Ekonomi Eksklutif Indonesia

tercantum pada Tabel 2 .

Semenjak diundangkannya Undang-Undang Nomor 22 Tahun 1999 tentang Otonomi Daerah (UU No. 22/1999), kebijakan pembangunan pendidikan secara sentralistis berangsur-angsur diberikan kepada daerah otonom dalam bentuk kewenangan untuk mengelola pendidikan.sesuai dengan potensi dan kebutuhan daerah masingmasing. Kewenangan tersebut berupa hak mengatur, mengelola dan mengembangkan program-program pendidikan sesuai dengan potensi dan dukungan masyarakat setempat dan sekitarnya melalui pendekatan manajemen berbasis sekolah (MBS). Oleh karena itu, Pemerintah memberi peluang bagi setiap daerah untuk mengelola dan mengembangkan potensi daerahnya masing-masing (termasuk bidang pendidikan). Peluang dimaksud antara lain dalam mengembangkan pendidikan kejuruan yang relevan dengan bidang lainnya, yaitu bidang perikanan.

Setiap pemerintah daerah, berkepentingan dan berpeluang untuk mengembangkan pendidikan kejuruan (SMK). Pengembangan SMK tidak hanya mengarah pada kuantitas, melainkan juga kualitas sebagaimana diamanatkan UU No.20/2003 tentang Sistem Pendidikan Nasional (Pasal 50 ayat 3 dan 5) yaitu mengembangkan salah satu model satuan pendidikan bertaraf internasional dan/atau berbasis keunggulan lokal sesuai dengan potensi daerahnya masing-masing. Penataan ulang (re-engineering) SMK memungkinkan pula untuk dikembangkannya SMK berdasarkan potensi daerah masing-masing sesuai dengan kebutuhan dan pembangunan di masing-masing daerah tingkat provinsi/kabupaten/kota.

Salah satu potensi daerah yang belum dikembangkan secara optimal antara lain wilayah pesisir yang sebagian besar wilayahnya dikelilingi laut. Potensi laut Indonesia sangat kaya dengan berbagai ragam ikan dan rumput laut. Oleh karenanya, daerah yang memiliki wilayah pesisir dapat mengembangkan SMK sebagai alternatif pengembangan program keahlian/kejuruan, seperti misalnya: a) Teknologi Pengolahan Ikan; b) Pengolahan Tradisional atau Modern; c) Pengolahan Rumput Laut; d) Teknologi Budidaya Rumput Laut; e) Budidaya Ikan di Kolam Air Tawar; f) Budidaya Ikan dengan Pola Minapadi; g) Budidaya Ikan dengan Air Tawar dengan Pola Keramba; h) Budidaya Ikan Air Payau (Tambak); i) Pengolahan Hasil Kelautan dan Perikanan; j) Teknologi penangkapan ikan. Pengembangan dan penyelenggaraan program-program keahlian/ kejuruan tersebut harus mempertimbangkan ketersediaan sarana-prasarana dan institusi pasangan yang ada di daerah masing-masing serta dapat dilakukan melalui kerja sama dan/atau berbagi (sharing) dengan instansi terkait, baik dalam hal SDM (pendidik dan tenaga kependidikan maupun pemanfaatan sarana teknologi, informasi, dan komunikasi (TIK).

Terkait dengan pengembangan SMK, Ace Suryadi (2004) berpendapat bahwa ke depan, SMK merupakan salah satu komponen pendidikan yang perlu dikembangkan di Indonesia. Bahkan, diprediksikan suatu saat, jumlah peserta didik SMK akan lebih banyak dibandingkan dengan jumlah peserta didik SMA karena tujuan SMA dimaksudkan untuk memberikan bekal kompetensi kepada peserta didik untuk melanjutkan pendidikan ke janjang yang lebih tinggi. Hal ini berarti bahwa Kemdiknas telah mempertimbangkan akan kebutuhan tenaga kerja tingkat menengah yang siap latih/kerja sesuai dengan kebutuhan dan tuntutan era global yang kompetitif. Pada hakikatnya, pengembangan SDM merupakan salah satu isu dalam rangka persiapan menghadapi era globalisasi, baik dalam persiapan jangka pendek sesuai dengan kesepakatan AFTA tahun 2003 maupun persiapan jangka panjang sesuai dengan kesepakatan pasar bebas 2020. Hal ini sejalan dengan kebijakan pendidikan kejuruan yang 
tertuang dalam "Keterampilan 2020" (Depdikbud, 1995).

\section{Analisis kondisi SMK}

Dalam upaya peningkatan kualitas lulusan SMK, Kemdiknas sejak tahun 1993 telah menerapkan kebijakan link and match (keterkaitan dan kesepadanan) di SMK. Konsep link and match berorientasi pada pemberian kompetensi kepada peserta didik (teori di sekolah) dan praktik di industri agar tercipta suatu keseimbangan antara dunia sekolah dengan dunia industri sesuai kebutuhan pasar (demand driven). Bahkan, orientasi kebutuhan pasar dikembangkan secara bertingkat, dari tingkat kebutuhan lokal, nasional, regional sampai pada tingkat global/ internasional. Perkembangan teknologi berimplikasi pada pembekalan keterampilan vokasional kepada siswa SMK.

Menurut, Ki Supriyoko, (2004) ada beberapa prinsip pendidikan kejuruan yang harus diperhatikan, antara lain: 1) pendidikan kejuruan harus dapat dilaksanakan secepat mungkin (education in short); 2) pendidikan kejuruan dalam pengembangannya harus berorientasi pada jenisjenis pekerjaan yang dibutuhkan di lapangan kerja (job orientation); 3) pendidikan kejuruan diatur sedemikian rupa supaya peserta didik dapat keluar masuk lembaga pendidikan secara mudah (free entry-exit); 4) Pendidikan kejuruan harus disesuaikan dengan permintaan pasar (demand driven) bukan pasar yang menyesuaikan pendidikan kejuruan; 5) pengembangan pendidikan kejuruan harus terbuka atau terjadinya interaksi antardisiplin ilmu serta disiplin teknologi/cross discipline; dan 6) pendidikan kejuruan harus berani mengembangkan teknologi yang sedang dan akan berkembang (forward technology).

Sekurang-kurangnya pendidikan kejuruan di Indonesia pada saat ini menghadapi tiga tantangan besar, yaitu: 1) tantangan terhadap dampak krisis ekonomi, sehingga pendidikan kejuruan dituntut untuk dapat mempertahankan hasil-hasil pendidikan kejuruan yang telah tercapai; 2) kemampuan mengantisipasi era global, sehingga pendidikan kejuruan dituntut untuk mempersiapkan SDM yang kompeten agar mampu bersaing dalam pasar kerja global; dan 3) konsekuensi diberlakukannya otonomi daerah.
Oleh karena itu, perlu dilakukan perubahan dan penyesuaian pendidikan kejuruan secara bertahap dan berkesinambungan dengan perkembangan IPTEKS dan kebutuhan dunia usaha dan dunia industri. Penyelenggaraan pendidikan kejuruan hendaknya mempertimbangkan aspek demokrasi dan berkeadilan dengan memperhatikan keberagaman kebutuhan/ keadaan daerah dan peserta didik, serta mendorong peningkatan partisipasi masyarakat (khususnya masyarakat industri).

Adanya kebijakan Kemdiknas untuk menambah jumlah SMK secara proporsional, mengindikasikan adanya perhatian Kemdiknas dalam penyeleng-garaan SMK agar lebih proporsional dan profesional. Penambahan jumlah program keterampilan pada sekolah umum (SMA) merupakan kebijakan yang perlu dilakukan secara bertahap dan berkesinambungan. Menurut Priowirjanto, (2004) rata-rata penambahan jumlah SMK sebanyak 50 setiap tahunnya. Bahkan, pada tahun 2004 Depdiknas telah mendirikan 240 SMK dengan menempel pada institusi sekolah yang telah ada. Pemerintah juga memperbesar daya tampung SMK di 28 kota dengan mengefektifkan penggunaan ruang mulai pagi sampai malam hari. Lebih lanjut, Priowirjanto berharap bahwa ke depan, jumlah peserta didik SMK dibandingkan denga SMA dapat mencapai satu banding satu (1:1). Jika hal ini terwujud, ini berarti bahwa kebijakan Kemdiknas mempertimbangkan kebutuhan tenaga kerja tingkat menengah yang siap latih/kerja sesuai dengan kebutuhan dan tuntutan era global yang kompetitif.

Berbagai upaya telah dan sedang dilakukan Direktorat Pendidikan Menengah Kejuruan, Ditjen Pendidikan Menengah pada prinsipnya bermuara pada upaya meningkatkan kualitas tamatan (SDM) SMK. Upaya dimaksud mencerminkan peningkatan, pembaharuan di berbagai aspek pendidikan mencakup pendidik, sarana dan prasarana pendidikan, materi dan metodologi pembelajaran. Pada sepuluh tahun terakhir, penerapan filosofi link and match melalui program pendidikan dual system atau pendidikan sistem ganda (PSG) merupakan upaya yang signifikan untuk meningkatkan kualitas tamatan SMK. Semenjak tahun 1996, Kemdiknas menerapkan kebijakan link and match (keterkaitan dan kesepadanan) 
pada pendidikan SMK. Konsep link and match berorientasi pada kebutuhan pasar (demand driven) yang saling berkaitan antara SMK, siswa, orangtua siswa dan dunia usaha. Bahkan, orientasi kebutuhan pasar dikembangkan secara bertingkat, dari tingkat kebutuhan lokal, nasional, regional sampai pada tingkat global/ internasional.

Perintisan 5 SMK model PSG dilakukan mulai tahun ajaran 1993/1994, di mana Depdikbud bekerjasama dengan Pemerintah Jerman melalui GTZ (German Technical fur Zuzammmenarbeit). Kelima SMK dimaksud yaitu: SMKN 57 (SMIP) Jakarta, SMKN 1 (STM) Karawang, SMKN 2 (SMEA) Semarang, SMKN 5 (STM Pembangunan) Surabaya, dan SMKN 1 Percut Sei Tuan (STM) Medan. Pada tahun ajaran 1995/1996 menyusul 14 SMKN terpilih di pulau Jawa menerapkan PSG dengan bimbingan dan kerja sama Badan Pengelola Industri Strategis (BPIS). Selanjutnya, pada tahun ajaran 1996/1997 selain 5 SMK model dan 14 SMK binaan BPIS lainnya menerapkan PSG dengan menekankan pola pembelajaran praktik kerja di industri (prakerin), sehingga pada akhirnya diberlakukan pula untuk seluruh SMK baik negeri maupun swasta untuk menyelenggarakan program PSG yang diperkuat dengan Keputusan Mendikbud No. 327/U/1997 tentang Penyelenggaraan PSG pada SMK.

Berbagai permasalahan pendidikan kejuruan, yang telah, sedang dan belum teratasi disadari sepenuhya oleh Kemdiknas. Oleh karenanya, berbagai upaya telah dilakukan Direktorat Pendidikan Menengah Kejuruan dari tahun ke tahun menaruh perhatian yang mengarah pada peningkatan kualitas SMK (Depdikbud, 1995). Hal tersebut sejalan dengan kebijakan Depdiknas yang memberikan perhatian khusus pada peningkatan mutu pendidikan pada semua jenis dan jenjang dengan memusatkan perhatian pada tiga faktor, yaitu: 1) ketersediaan sumber-sumber pendidikan yang memadai untuk menunjang proses pendidikan, 2) proses pelaksanaan pendidikan, dan 3) mutu tamatan (Djoyonegoro, 1995).

Berdasarkan kebijakan tersebut maka betapa pentingnya peningkatan mutu dan relevansi pendidikan terhadap kebutuhan dunia kerja, sehingga hasil pengelolaan dan penyelenggaraaan pendidikan yang efisien khususnya pendidikan kejuruan (SMK) mampu memenuhi kebutuhan pembangunan. Djoyonegoro, (1995) dalam melaksanakan pembangunan pendidikan, Depdikbud telah menetapkan empat pokok kebijakan yakni peningkatan: 1) pemerataan, 2) mutu, 3) relevansi, serta 4) efesiensi pelaksanaan pendidikan. Dalam pelaksanaan kebijakan tersebut antara yang satu dengan lainnya saling berkaitan. Dalam hal pemerataan pendidikan misalnya harus memperhatikan dan mempertimbangkan efisiensi, begitu pula dalam hal relevansi dapat terkait dengan hasil peningkatan mutu pendidikan.

Mengacu pada permasalahan pendidikan kejuruan yang mendasar, maka upaya yang berkaitan dengan peningkatan mutu dan relevansi pendidikan serta SDM dapat dilakukan melalui berbagai hal. Untuk meningkatkan mutu tamatan misalnya, dapat dilakukan pengembangan pendidikan sistem ganda (PSG), pengembangan kurikulum berbasis kompetensi (saat ini KTSP), uji kompetensi dan sertifikasi, peningkatan pengetahuan dan keterampilan guru dan instruktur (di sekolah, di BLPT, dan magang di industri), pembelajaran yang bermakna, penyediaan peralatan laboratorium dan praktik yang memadai, penggunaan dan pengelolaan peralatan praktik secara optimal, serta tidak kalah pentingnya terciptanya kerja sama dengan institusi pasangan di DUDI secara kondusif dan dapat menimbulkan saling pengertian (mutual understanding) dan saling menuntungkan (mutual benefit).

Kerja sama tersebut dimaksudkan sebagai upaya mempersiapkan angkatan kerja yang produktif, sehingga program pendidikan mampu memberikan kemampuan dan keterampilan profesional yang dapat dikembangkan melalui program pelatihan di industri. Oleh karenanya, kurikulum pendidikan SMK merupakan pedoman penyelenggaraan pendidikan dan keterampilan dasar kejuruan yang bersifat dinamis. Peyelenggaraan program pendidikan dalam pelatihan keterampilan dasar kejuruan di SMK secara bertahap dan berkesinambungan akan terus ditingkatkan dengan memperhatikan efisiensi dan efektivitas penggunaan jam mengajar teori dan praktik. Dengan demikian, apabila efektivitas dan efisiensi pembelajaran dapat dilaksanakan secara optimal maka hal tersebut akan dapat mempengaruhi tingkat kompetensi keterampilan yang 
harus dikuasai oleh peserta didik.

Secara umum, keberhasilan dalam melaksanakan program pendidikan kejuruan tidak hanya tergantung pada kurikulum, namun faktor lain yang terkait seperti kualitas dan jumlah tenaga pendidik, sarana dan prasarana praktik yang memadahi serta efektivitas penggunaan jam mengajar di kelas/laboratorium/bengkel. Mengingat sarana peralatan praktik yang diperlukan di SMK pada umumnya cukup mahal maka dalam upaya meningkatkan efisiensi dan efektivitas pengadaan dan pemakaian peralatan praktik, keberadaan peralatan praktik diharapkan dapat melayani kebutuhan praktik siswa SMK secara optimal. Di samping itu, kerja sama dengan dunia usaha dan industri juga sangat diperlukan. Pelaksanaan praktik yang efisien diharapkan dapat meningkatkan mutu pendidikan SMK dan sekaligus mencerminkan hasil proses belajar mengajar yang optimal. Untuk proses pematangan individu dalam menghadapi tugas dan tanggung jawab secara nyata di dunia kerja dapat diperoleh melalui program PSG yang telah ditetapkan sebagai suatu kebijakan "link and match" khususnya pada pendidikan kejuruan (Djoyonegoro, 1994).

Efisiensi pendidikan sangat erat kaitannya dengan pendayagunaan sumber daya pendidikan secara optimal. Program pendidikan yang efisien dapat tercermin pada bagaimana institusi mampu mendistribusikan sumber-sumber pendidikan yang ada secara optimal. Dengan demikian, pengertian mutu pendidikan tidak dapat terpisahkan dengan konsep efektivitas dan efisiensi penggunaan sumber daya pendidikan. Asumsi yang pada umumnya dijadikan acuan dalam studi tentang mutu pendidikan adalah "semakin tinggi kemampuan belajar siswa maka semakin tinggi kemungkinan siswa yang bersangkutan memiliki prestasi belajar yang baik".Implikasi pelaksanaan otonomi daerah terhadap aspek pendidikan, desentralisasi pendidikan memberi kewenangan yang seluas-luasnya kepada daerah untuk mengembangkan pendidikan di daerahnya masing-masing, namun masih tetap dalam koridor untuk mencapai tujuan pendidikan nasional.

Pemerintah daerah sangat berkepentingan dan berpeluang dalam pengembangan pendidikan kejuruan antara lain menjadikan SMK sebagai salah satu model pendidikan bertaraf internasional dan/atau berbasis keunggulan lokal sesuai dengan potensi daerahnya masing-masing. Di samping itu, SMK dapat dijadikan sebagai pusat pelatihan keterampilan terpadu (PPKT). Penataan ulang (re-engineering) SMK memungkinkan untuk dikembangkan berdasarkan potensi daerah masing-masing sesuai dengan kebutuhan bidang pekerjaan tersebut di atas.

Mengacu pada analisis pendidikan kejuruan tersebut di atas maka disimpulkan bahwa permasalahan yang berkaitan dengan penyelenggaraan SMK di daerah yaitu: a) perbandingan antara jumlah SMK yang diperlukan dengan SMK yang ada belum proporsional; b) dalam penyelenggaraan pendidikan kejuruan belum terciptanya link and match antara kompetensi lulusan dan kebutuhan kompetensi tenaga kerja tingkat menengah yang dibutuhkan oleh industri sesuai dengan potensi daerah masing-masing; c) tingkat kesiapan pemerintah daerah dalam menyiapkan calon tenaga kerja tingkat menengah di era otonomi daerah belum merata, di mana ada daerah yang sangat berpotensi untuk mengembangkan pendidikan kejuruan (SMK) kurang mempertimbangkan potensi daerah.

Sekalipun demikian, dalam era otonomi daerah masing-masing daerah memiliki potensi yang sama untuk mengembangkan SMK sesuai dengan potensi daerah masing-masing. Pengembangan dimaksud termasuk pengembangan SMK bertaraf internasional dan/atau pengembangan SMK dengan keunggulan lokal dan potensi daerah. Hal tersebut merupakan salah satu amanat UU 20/2003 (Pasal 50 ayat 3 dan 5). Dengan demikian, setiap provinsi berpeluang untuk mengembangkan dan/atau menambah jumlah SMK sesuai dengan potensi dan kebutuhan masing-masing. Potensi dimaksudkan meliputi: ketersediaan SDM, kebutuhan pembangunan daerah, ketersediaan sumber alam yang dimiliki sehinga terwujud penyediaan tenaga kerja tingkat menengah (SMK) dengan kebutuhan daerah (suply and demand) di masing-masing daerah. Untuk itulah diperlukan perencanaan dan kesiapan pemerintah daerah dalam menyiapkan calon tenaga kerja tingkat menengah di era otonomi daerah secara terencana dan berkesinambungan. 


\section{Perkiraan Kebutuhan Tenaga Kerja di Indonesia}

Indonesia merupakan negara dengan kekayaan potensial yang melimpah baik dari kekayaan alamnya maupun karena posisinya yang strategis di jalur perdagangan dunia. Sayangnya, kekayaan potensial yang melimpah tersebut belum dapat dikelola dan dimanfaatkan oleh rakyat Indonesia secara merata. Hal ini antara lain disebabkan karena masih rendahnya tingkat pendidikan (keterbatasan skill dan mindset masyarakat yang masih pada taraf pekerja tingkat rendah).

Diperkirakan pada tahun 2025, Indonesia akan menjadi salah satu negara yang besar, dengan potensi kekayaan alam yang melimpah. Di bidang perekonomian, Menteri Koordinasi Ekonomi, Hatta Rajasa menyatakan bahwa pada tahun 2025, Indonesia akan masuk tujuh kekuatan ekonomi dunia (http://webcache.google. user.content.com/search?). Hal senada juga dikemukakan oleh Menteri Perindustrian Hidayat menyatakan bahwa saya melihat pada 2025 mimpi kita sebagai basis produksi bisa menjadi pembangunan kelautan 2007-2025 lebih menekankan pada pembangunan industri pelayaran, perikanan dan pariwisata bahari (http://www.suarakarya. online.com/news. html?id=231888). Dengan mengacu pada perkiraan tersebut, produksi otomotif juga masuk tujuh kekuatan ekonomi dunia di mana memerlukan dukungan SDM yang banyak dan kompeten di berbagai sektor seperti pertanian, perikanan, perdagangan, teknologi informasi, perhotelan, jasa, otomotif dan lain sebagainya.

Dapat diantisipasi bahwa kebutuhan tenaga kerja pada sektor tersebut lebih condong pada tenaga kerja yang siap kerja dan pendidikan menengah maupun tenaga kerja yang mampu melakukan usaha sendiri (berwirausaha). Kebutuhan tenaga kerja yang sangat banyak tersebut secara langsung akan membuka kesempatan kerja bagi angkatan kerja, terutama dengan kompetensi yang diperlukan.

Sebagai prediksi kebutuhan tenaga kerja, dapat dicermati sebagaimana terdapat pada Tabel 3 berikut.

Tabel 3. Perkiraan Pertumbuhan Angkatan Kerja dan Kesempatan Kerja

\begin{tabular}{|c|c|c|c|}
\hline No & Tahun & Angkatan Kerja & Kesempatan Kerja \\
\hline 1 & 1998 & 12.704 .000 & 11.913 .000 \\
\hline 2 & 2003 & 13.232 .000 & 12.427 .000 \\
\hline 3 & 2008 & 12.701 .000 & 12.744 .000 \\
\hline 4 & 2013 & 12.095 .000 & 12.177 .000 \\
\hline 5 & 2018 & 11.455 .000 & 11.871 .000 \\
\hline
\end{tabular}

Sumber:Simanjuntak, 1996 dalam Balitbang (2009)

kenyataan (http://www.businessreview.co.id/ bisnis-investasi-751.html. Di sektor lain pun tidak kalah pentingnya adalah di bidang perkebunan dan perikanan. Susila dalam penelitiannya menyatakan bahwa sampai dengan 2025 diprediksi akan ada peluang peningkatan produksi CPO antara 15,78 - 18,78 juta ton, dan Indonesia diperkirakan mampu memperoleh peluang terbesar sekitar $40 \%$ atau $6,31-7,51$ juta ton (http://ejournal. unud.ac.id/abstrak/(6)\%). Hal yang sama juga terjadi di bidang perikanan, Syamsul menyatakan peluang pengembangan usaha kelautan dan perikanan di Indonesia memiliki prospek yang baik, baik perikanan laut maupun darat. Oleh karena itu, grand strategi
Berdasar prediksi tersebut, di masa mendatang kesempatan kerja akan lebih banyak daripada angkatan kerja, bahkan akan terjadi kekurangan angkatan kerja. Hal ini dapat terjadi manakala kondisi perekonomian Indonesia dapat stabil dan/ atau meningkat. Di samping itu, kualitas SDM Indonesia di setting untuk siap kerja dengan skill yang kompeten (terutama SDM tingkat menengah). Tabel 4 menunjukkan adanya perkembangan kebutuhan tenaga kerja di berbagai bidang usaha.

\section{Simpulan dan Saran Simpulan}

Berdasarkan uraian di atas, dapat disimpulkan 
Subijanto, Potensi Kekayaan Alam Kelautan Mendukung Terwujudnya Kebijakan Kemdiknas Dalam Mewujudkan Peningkatan Jumlah SMK ...

Tabel 4. Kontribuasi Lapangan Usaha terhadap Pertumbuhan PDB Nasional (\%)

\begin{tabular}{|l|l|r|r|r|r|r|}
\hline No. & \multicolumn{1}{|c|}{ Lapangan Usaha } & 2005 & 2006 & 2007 & 2008 & 2009 \\
\hline 1 & $\begin{array}{l}\text { Pertanian, Peternakan, kehutanan } \\
\text { dan perikanan }\end{array}$ & 13,1 & 13 & 13,7 & 14,5 & 15,3 \\
\hline 2 & Pertambangan dan penggalian & 11,1 & 11 & 11,2 & 10,9 & 10,5 \\
\hline 3 & Industri pengolahan & 27,4 & 27,5 & 27 & 27,9 & 26,4 \\
\hline 4 & Listrik, gas dan air bersih & 1 & 0,9 & 0,9 & 0,8 & 0,8 \\
\hline 5 & Konstruksi & 7 & 7,5 & 7,7 & 8,5 & 9,9 \\
\hline 6 & Perdagangan, hotel dan restoran & 15,6 & 15 & 15 & 14 & 13,4 \\
\hline 7 & Pengangkutan dan komunikasi & 6,5 & 6,9 & 6,7 & 6,3 & 6,3 \\
\hline & $\begin{array}{l}\text { Keuangan, real estate dan jasa } \\
\text { perusahaan }\end{array}$ & 8,3 & 8,1 & 7,7 & 7,4 & 7,2 \\
\hline 9 & Jasa & 10 & 10,1 & 10,1 & 9,7 & 10,2 \\
\hline & Total kontribusi sektoral & 100 & 100 & 100 & 100 & 100 \\
\hline & Pertumbuhan PDB Nasional & 5,7 & 5,5 & 6,3 & 6 & 4,5 \\
\hline
\end{tabular}

Sumber: BPS, dalam Suara Pembaharuan, Kamis 5 Agustus 2010.

sebagai berikut. Pertama, potensi kekayaan alam kelautan dapat dijadikan pertimbangan dalam mendukung kebijakan Kemdiknas dalam mewujudkan peningkatan proporsi Jumlah SMK dibandingkan dengan SMA, khususnya pada era otonomi daerah. Kedua, rasionalisasi proporsi SMK: SMA dengan target 70:30, antara lain berdasarkan pertimbangan bahwa: a) SMK sebagai lembaga pendidikan penghasil calon tenaga kerja tingkat menengah yang dianggap dapat menjembatani antara kebutuhan masyarakat dengan kebutuhan dunia usaha dan dunia industri; b) SMK berfungsi sebagai fungsi ekonomi, sehingga diharapkan dapat menciptakan kondisi yang seimbang antara ketersediaan lapangan kerja dengan ketersediaan tenaga terampil tingkat menengah khususnya dari tamatan SMK; c) SMK memiliki keterampilan dasar untuk bekerja; d) lulusan SMK lebih menjanjikan untuk dapat menghidupi dirinya melalui bekerja dan didukung oleh keterampilan yang dimilikinya (life skill), e) lulusan SMK mempunyai kebiasaan latihan bekerja, meskipun belum terampil sesuai dengan tuntutan industri, namun sekurangkurangnya telah memiliki kebiasaan bekerja, secara mandiri, secara berkelompok, maupun perorangan dengan membuka usaha kecil di bidang perikanan, pertanian, peternakan, bengkel, dan lain sebagainya, e) pengembangan program SMK mampu mensinergikan seluruh sumber daya yang tersedia di masyarakat, sehingga terjadi efisiensi dalam pendayagunaan
SDM alumni SMK, dan f) mengurangi jumlah pengangguran. Ketiga, faktor ekonomi yang harus diperhatikan dalam penentuan proporsi SMK:SMA yaitu jumlah DUDI baik dalam bentuk manufaktur, jasa, maupun perdagangan yang ada di daerah, termasuk industri kerajinan rakyat/UKM, daerah tujuan wisata, hotel, dan lain-lain; Keempat, faktor geografi yang harus diperhatikan dalam penentuan proporsi SMK:SMA adalah jumlah sumber daya alam (perikanan, pertambangan, perkebunan) dan lain-lain; Kelima; faktor sosial yang harus diperhatikan dalam penentuan proporsi SMK:SMA meliputi aspirasi dan partisipasi masyarakat terhadap SMK. Hal ini sangat penting diperhatikan karena menyangkut motivasi masyarakat menyekolahkan putra-putrinya ke SMK untuk siap bekerja dan/atau untuk melanjutkan pendidikan (vokasi) yang lebih tinggi. Keenam, faktor potensi daerah perlu diperhatikan dalam penentuan proporsi SMK:SMA, yaitu potensi sumber daya alam dan kemauan pemerintah daerah (political will) terhadap pembangunan SMK dan strategi pemerintah provinsi/kabupaten/kota dalam penentuan proporsi SMK:SMA. Ketujuh, faktor demografi yang harus mendapat perhatian dalam penentuan proporsi SMK:SMA antara lain menyangkut jumlah penduduk pada suatu wilayah, jumlah penduduk usia sekolah, jumlah penduduk pencari kerja, dan lain sebagainya.

\section{Saran}

Berdasarkan simpulan di atas, beberapa saran 
yang direkomendasikan untuk menjadi perhatian untuk dipertimbangkan dalam menentukan proporsi SMK:SMA sebagai berikut. Pertama, faktor kekayaan kelautan agar dipertimbangkan sebagai salah satu pertimbangan mendasar dalam menambah proporsi jumlah SMK. Kedua, faktor potensi daerah seperti kondisi perekonomian daerah, sumber daya alam, geografi, sosial, dan demografi perlu diperhatikan dalam penentuan proporsi SMK. Dengan kata lain kebutuhan DUDI (demand driven) hendaknya lebih diutamakan daripada menyiapkan lulusan/pasokan SMK (supply driven). Ketiga, pengembangan SMK hendaknya memperhatikan mutu dan relevansinya dengan kebutuhan DUDI. Oleh karena itu, apabila kebijakan proporsi 70:30 akan diwujudkan maka perlu meningkatkan mutu SMK sehingga mampu memenuhi tuntutan delapan standar nasional pendidikan (SNP) dan memenuhi tuntutan dunia usaha/dunia kerja. Oleh karena itu, untuk mencapai proporsi yang diinginkan perlu dilakukan upaya peningkatan kualitas di segala aspek untuk memenuhi tercapainya SNP di SMK melalui sharing dengan instansi terkait dalam hal pendidik/ instruktur; pemanfaatan teknologi informasi dan komunikasi (TIK), dan integrasi penyelenggaraan (akreditasi). Namun, manakala mutu tamatan SMK tidak dapat memenuhi standar minimal (8 SNP), maka kebijakan tersebut perlu ditinjau kembali. Keempat, pembangunan SMK hendaknya mendapat dukungan yang kuat (political will) baik dari DPRD, Bappeda, DUDI, masyarakat dan para pemangku kepentingan (stakeholders).

\section{Pustaka Acuan}

Anonim, 2010. Starategi Pembangunan Kelautan 2007-2025, dalam http://www.suarakarya. online.com/news.html?id=231888, diakses pada tanggal 5 Januari 2010.

Badan Penelitian dan Pengembangan, 2009, Indonesia Statistics in Brief, Pusat Data dan Informasi Pendidikan, Jakarta.

Badan Penelitian dan Pengembangan, 2009, Studi Proporsi SMK:SMA, Sekretariat Balitbang Kemdiknas, Jakarta.

Badan Pusat Statistik, 2010. Kontribuasi Lapangan Usaha terhadap Pertumbuhan PDB Nasional. Suara Pembaharuan, Kamis 5 Agustus 2010

Departemen Pendidikan dan Kebudayaan,1995, Keterampilan Menjelang 2020 Untuk Era Global, Depdikbud, Jakarta.

Departemen Pendidikan dan Kebudayaan,1995, Program Pengembangan Dikmenjur tahun 1995/1996: Disiapkan untuk Penataran Lokal Kepala Bidang Dikmenjur seluruh Indonesia, Dit.Dikmenjur, Jakarta.

Departemen Pendidikan Nasional, 2003, Undang-Undang Nomor: 20 Tahun 2003 Tentang Sistem Pendidikan Nasional, Jakarta.

Djojonegoro, Wardiman. 1995. Peran Masyarakat Dalam Pengembangan Pendidikan Berwawasan Keunggulan: Makalah disampaikan pada Muktamar Muhamadiyah ke 42 di Banda Aceh, Depdikbud, Jakarta.

Djojonegoro, Wardiman. 1994. The Meaning of Link and Match, presented at the Luncheon of the "Deuthches Forum" Jakarta, December 13, Ministry of Education and Culture,Republic of Indonesia.

Hidayat, Sulaiman. Basis Produksi Indonesia. 2010. dalam http://www.businessreview.co.id/bisnisinvestasi-751.html, diakses pada tanggal 27 November 2010.

Susila, Peluang Produksi CPO, 2009. dalam http://ejournal. unud.ac.id/abstrak/(6)\%, diakses pada tanggal 15 Desember 2009

Pratikto, Widi, A. 2005, Makalah pada Sambutan Seminar Sehari Pengembangan Pendidikan dasar dan Menengah Berwawasan Kelautan" 30 Agustus 2005.

Rajasa, Hatta, Kekuatan Ekonomi Dunia, dalam http://webcache.google. user.content.com/search, diakses pada tanggal 3 Desember 2009.

Supriyoko, 2004. Pembaharuan SMK Dalam Hal Pelaksanaannya, Jakarta 
Suryadi, Ace, 2004, Perkembangan SMK dalam www.kompas.co.id, diakses pada tanggal 7 Maret 2005

Sindhu A, Handono S; dan Adi Saputra, 2005, Program Penyusunan Paket Keahlian Kelautan Sebagai Pedoman Penyelenggaraan Kecakapan Hidup di SMA: Makalah disampaikan pada Seminar Pengembangan Pendidikan Dasar dan Menengah Berwawasan Kelautan, Ditjen Dikdasmen, Jakarta.

Surat Kesepakatan Bersama Antara Menteri Pendidikan Nasional Republik Indonesia dengan Menteri Kelautan dan Perikanan Republik Indonesia Nomor: 06/Xii/KB/2004 dan Nomor: 09/KB/Dep KP/ 2004 Tentang Pengembangan Mitra Bahari (PMB).

Undang-Undang Nomor 22 Tahun 1999 tentang Pemerintah Daerah 